\title{
PENGARUH KOMITMEN ORGANISASIONAL DAN PROFESIONAL TERHADAP KEPUASAN KERJA PEGAWAI DENGAN MOTIVASI SEBAGAI VARIABEL INTERVENING DIKANTOR DINAS PENDIDIKAN KEPEMUDAAN DAN OLAHRAGA KABUPATEN SOLOK SELATAN
}

\author{
Darnawati, Aminar Sutra Dewi \\ Sekolah Tinggi Ilmu Ekonomi KBP \\ darnawati12121995@gmail.com
}

\begin{abstract}
This study aims to determine the significant influence of Organizational and Professional Commitment on Employee Job Satisfaction with Motivation as Intervening Variables. The population of this research is all civil servant employees who work in the Youth and Sports Education Office of South Solok Regency. The study sampling was determined using total sampling. The samples used in this study were 55 civil servants in the Department of Youth and Sports Education, South Solok Regency. Data was collected from respondents' results and analyzed by simple linear regression. The results of the study show that Organizational Commitment influences Job Satisfaction positively and significantly, professional influences job satisfaction positively and significantly, Organizational Commitment influences Motivation positively and significantly, Professional influences motivation positively and significantly, Motivation influences job satisfaction positively and significantly, Organizational Commitment with motivation as an intervening variable indirectly influences Employee job satisfaction, Direct professional influence with motivation as an intervening variable on Employee job satisfaction, is actually greater than indirect influence. The results of the study indicate that organizational commitment has the greatest influence on Employee job satisfaction Therefore, organizational commitment needs to be improved by the Department of Youth and Sports Education of South Solok Regency.
\end{abstract}

Keywords: Organizational, Professional, Motivation and Job Satisfaction

\section{PENDAHULUAN}

Kepuasan kerja atau job satisfaction merupakan suatu perasaan positif mengenai pekerjaan seseora ng merupakan hasil dari evaluasi karakteristik-karakteristik yang akan bersangkutan dengan kepuasan kerja seorang karyawan Robbins \& Judge, (2008).Berdasarkan pengamatan penulis, permasalahan yang ada yaitu masalah fasilitas kantor di perusahaan yang masih kurang, kedisiplinan jam kantor para staf atau pegawai yang efisiensi, Job description tidak jelas atau bosan tidak ada 
kerjaan pada melakukan pekerjaan di perusahaan tersebut.Dan tidak adanya kepuasan kerja pada pegawai pada saat bekerja karena pimpinannya yang kurang efektif dan kurang perhatian pada pegawainya di karenakan pimpinan sibuk dengan pekerjaan sendiri sehingga kurangnya perhatian dari pimpinan kepada pegawai sehingga pegawai tidak puas atas apa yang di berikan oleh pemimpin.tahun 2016 tedapat beberapa kegiatan salah satunya, pendidikan dan pelatihan teknis PNS daerah, peningkatan kualitas SDM Dinas pendidikan kepemudaan dan olahraga, Pengadaan alat dan media pembelajaran, Penyuluhan pencegahan penggunaan narkoba, bahwa belum terlihat kepuasan kerja pada pegawai karna banyak pegawai yang tidak mau mengikuti kegiatan tersebut alasannya tidak ada peningkatan dalam karir apa lagi kegiatan kualitas pegawai di dinas pendidikan kepemudaan dan olahraga. Berdasarkan permasalahan diatas, perlu dilakukan penelitian apakah faktor komitmen organisasional dan profesional juga dapat mempengaruhi kepuasan kerja pegawai yang berikutnya relatif mempengaruhi motivasi sebagai variabel intervening. Penelitian ini akan menganalisa pengaruh komitmen organisasional dan profesional terhadap kepuasan kerja pegawai dengan motivasi sebagai variabel intervening. Dimana penelitian ini akan dilakukan pada Kantor Dinas Pendidikan,Kepemudaan dan Olahraga Kabupaten Solok Selatan.

Fenomena kepuasan kerja adalah fenomena yang perlu diperhatikan karena kepuasan mempengaruhi kinerja. Hal ini didasari terhadap hasil penelitian Listianto dan Setiaji (2008) Bahwa kepuasan kerja sangat menentukan kinerja karyawan. Tidak setiap karyawan yang bekerja pada sebuah perusahaan memiliki kepuasan kerja yang tinggi. Hal ini disebabkan karena pegawai dengan komitmen kerja yang tinggi memiliki tuntutan pekerjaan yang lebih rendah, sehingga akhirnya karyawan lebih cepat puas dibandingkan karyawan dengan komitmen kerja yang lebih rendah. Permasalahan yang terdapat di dalam Dinas Pendidikan Kepemudaan Dan Olahraga Kabupaten Solok Selatan itu ialah tidak adanya kepuasan kerja pegawai dalam melaksanakan apa pun pekerjaan yang di lakukan seorang pegawai dalam melaksanakan tugas yang di berikan atasannya karena atasannya tidak ber komitmen dengan pegawainya atau pun tidak ada ketegasannya sebagai atasan kepada pegawai dalam memimpin atau memberikan tugas kepada pegawai.

Permasalahan yang terdapat adalah bahwa kepuasan kerja merupan pertanda awal suatu komitmen organisasional tersebut bertolak belakang,karena komitmen mendahului kepuasan kerja,dengan komitmen setidaknya akan dapat mempengaruhi kinerja baik itu secara langsung maupun tidak langsung.Oleh karena itu,peneliti yang menguji hubungan tingkat kepuasan kerja dalam peningkatan komitmen organisasional dan komitmen profesional merupakan topik yang menarik untuk di angkat. Dalam mencapai kepuasan kerja, seseorang harus memiliki motivasi di dalam dirinya. Motivasi adalah situasi dan kondisi dalam diri seseorang yang mendorong seseorang untuk melaksanakan aktivitas tertentu.Motivasi di perlukan oleh suatu profesi untuk mengembangkan kemampuan diri dalam pekerjaan.

Komitmen organisasi merupakan dorongan dalam diri individu untuk berbuat sesuatu agar dapat menunjang keberhasilan organisasi dengan tujuan dan 
lebih mengutamakan kepentingan organisasi (Yudi Syarif, 2006).Komitmen Organisasi adalah kesetiaan manusia pada profesinya seperti yang telah dipahami oleh manusia tersebut, Agar seseorang dapat berperilaku dengan baik, maka dia harus memperhatikan sikap profesional yang diatur dalam kode etik. Etika profesional yaitu standar perilaku seseorang profesional yang dirancang untuk tujuan efektif dan idealistik sehingga membentuk perilaku seseorang yang teladan, bersifat nyata, dan dapat dipertanggung jawabkan secara hukum. Dalam sebuah federasi profesi ditekankan akan adanya tingkat tanggung jawab yang setinggitingginya yang diwujudkan dengan kerja berbobot sekaligus sebagai jaminan keberhasilan atas tugas yang dihadapinya.

Menurut (Oerip dan Uetomo,2000) Profesionalisme merupakan prilaku,cara,dan kualitas yang menjadi ciri suatu profesi.Seseorang disebut profesional jika pekerjaannya mempunyai ciri standar teknik atau etika suatu profesi.Etika yaitu standar prilaku seseorang profesional yang di rancang untuk tujuan praktis dan idealistis sehingga mendorong prilaku seseorang yang ideal, bersifat realisme,dan dapat di pertanggung jawabkan dengan berdasarkan hukum yang berlaku.

Motivasi adalah keadaan pribadi seseorang yang mendorong keinginan individu melakukan kegiatan tertentu guna mencapai suatu tujuan motivasi kerja berkaitan dengan hasil kerja individual sekaligus mempengaruhi kinerja organisasi. Anwari (2000) menyatakan bahwa dalam International Dictionary of Management motivasi diartikan sebagai proses atau faktor-faktor yang menyebabkan orang bertindak atau berlaku dalam cara tertentu. Memotivasi adalah mendorong seseorang untuk melakukan tindakan.Berdasarkan pengertian ini maka dapat dikatakan bahwa sebenarnya.

Motivasi merupakan keadaan dalam pribadi seseorang yang mendorong individu untuk melakukan kegiatan atau pekerjaan di dinas pendidikan kepemudaan dan olahraga baik yang berasal dari dalam maupun dari luar dirinya untuk melakukan suatu pekerjaan dengan semangat tinggi menggunakan semua kemampuan dan keterampilan yang dimilikinya guna mencapai tujuan organissipada masa yang akan datang.

\section{Pengaruh Komitmen organisasi terhadap kepuasan kerja}

Komitmen organisasi merupakan dorongan dalam diri manusia untuk berbuat sesuatu agar dapat menunjang keberhasilan organisasi dengan tujuan dan lebih mengutamakan kepentingan organisasi (Yudi Syarif, 2006). Rahadyan, Probo dan Andi, (2008) dimana penelitian tentang pengaruh tanggung jawab organisasional dan janji terhadap kepuasan kerja audit dengan motivasi sebagai variabel intervening, dimana hasilnya mempunyai pengaruh positif dan signifikan trhadap kepuasan kerja.

Trisnaningsih, (2001) Dimana penelitian tentang pengaruh komitmen organisasional dan tanggung jawabpada kepuasan kerja audit dengan motivasi sebagai variabel intervening. Dimana hasilnya beberapa penelitian terdahulu menerangkan bahwa komitmen organisasional berpengaruh positif terhadap kepuasan kerja. Achmad, (2009) Dimana penelitian tentang pengaruh komitmen organisasional dan tanggung jawab terhadap kepuasan kerja audit dengan 
motivasi sebagai variabel intervening. Dimana hasilnya mempunyai pengaruh positif yang signifikan terhadap kepuasan kerja.

H1 : Diduga Komitmen Organisasional berpengaruh positif dan signifikan terhadap Kepuasa Kerja.

\section{Pengaruh Profesional terhadap kepuasan kerja.}

Menurut (Oerip dan Uetomo,2000) Profesionalisme adalah sikap,cara,dan mutu yang menjadi ciri suatu profesi. Seseorang di katakan profesional apabila pekerjaannya memiliki ciri standar teknik atau sikap suatu profesi. Rahadyan, Probo dan Andi, (2008) Penelitian mempengaruhi komitmen organisasional dan frofesional pada kepuasan kerja audit dengan motivasi sebagai variabel intervening, dimana hasilnya mempunyai pengaruh positif dan signifikan trhadap kepuasan kerja. Dimana hasil penelitian mengungkapkan bahwa profesionalisme berhubungan positif dengan kepuasan kerja.

Achmad, (2009) Dimana penelitian tentang pengaruh komitmen organisasional dan profesional pada kepuasan kerja audit dengan motivasi sebagai variabel intervening. Dimana hasilnya mempunyai pengaruh positif yang signifikan pada kepuasan kerja. Achmad, (2013) Dimana penelitian tentang Pengaruh komitmen pada kepuasan kerja audit dengan motivasi sebagai variabel intervening. Dimana hasilnya mempunyai pengaruh positif signifikan pada kepuasan kerja.

H2 : Diduga Proffesional berpengaruh positif dan signifikan terhadap Kepuasa Kerja.

\section{Pengaruh komitmen organisasi terhadap motivasi}

Robbins \& Judge, (2008) Komitmen Organisasional adalah suatu keadaan di mana seorang karyawan memihak organisasi tertentu serta tujuan-tujuan dan kemauan untuk mempertahankan keanggotaan dalam organisasi tersebut. Rahadyan, Probo dan Andi, (2008) Dimana penelitian tentang pengaruh komitmen organisasional dan frofesional pada kepuasan kerja audit dengan motivasi sebagai variabel intervening, dimana hasilnya mempunyai pengaruh positif dan signifikan trhadap motivasi.

Achmad, (2009) Dimana penelitian tentang pengaruh komitmen organisasional dan profesional pada kepuasan kerja audit dengan motivasi sebagai variabel intervening. Dimana hasilnya mempunyai pengaruh positif yang signifikan terhadap motivasi. Achmad, (2013) Dimana penelitian tentang Pengaruh komitmen pada kepuasan kerja audit dengan motivasi sebagai variabel intervening. Dimana hasilnya mempunyai pengaruh positif signifikan pada motivasi.

H3 : Diduga Komitmen Organisasional berpengaruh positif dan signifikan terhadap Motivasi sebagai variabel intervening.

\section{Pengaruh Profesional terhadap Motivasi sebagai variabel intervening}

Menurut (Oerip dan Uetomo,2000) Profesionalisme adalah prilaku,cara,dan kualitas yang menjadi ciri suatu profesi. Seseorang di katakan profesional apabila pekerjaannya memiliki ciri standar teknik atau sikap suatu profesi. Rahadyan, Probo dan Andi, (2008) Dimana penelitian tentang pengaruh komitmen organisasional dan frofesional pada kepuasan kerja audit dengan 
motivasi sebagai variabel intervening, dimana hasilnya mempunyai pengaruh positif dan signifikan pada motivasi.

Achmad, (2009) Dimana penelitian tentang pengaruh komitmen organisasional dan profesional pada kepuasan kerja audit dengan motivasi sebagai variabel intervening. Dimana hasilnya mempunyai pengaruh positif yang signifikan pada motivasi. Achmad, (2013) Dimana penelitian tentang Pengaruh komitmen pada kepuasan kerja auditor dengan motivasi sebagai variabel intervening. Dimana hasilnya mempunyai pengaruh positif signifikan pada motivasi.

H4 : Diduga Profesional berpengaruh positif dan signifikan terhadap Motivasi sebagai variabel intervening.

Pengaruh Motivasi sebagai variabel intervening terhadap Kepuasan ke rja.

Menurut Robbins (2007) motivasi merupakan prosesyang berperan pada intensitas, arah, dan lamanya berlangsung upaya individu kearah pencapaian sasaran. Rahadyan, Probo dan Andi, (2008) Dimana penelitian tentang pengaruh komitmen organisasional dan frofesional pada kepuasan kerja audit dengan motivasi sebagai variabel intervening, yang hasilnya mempunyai pengaruh positif dan signifikan pada kepuasan kerja sebagai variabel intervening.

Achmad, (2009) dimana penelitian tentang pengaruh komitmen organisasional dan profesional pada kepuasan kerja audit dengan motivasi sebagai variabel intervening. Dimana hasilnya mempunyai pengaruh positif yang signifikan pada kepuasan kerja sebagai variabel intervening.

H5 : Diduga Motivasi sebagai variabel intervening berpengaruh positif dan signifikan terhadap kepuasan kerja.

\section{Pengaruh Komitmen Organisasional dengan Motivasi sebagai variabel intervening terhadap kepuasan kerja}

Menurut Robbins dan Judge (2008) Komitmen Organisasional adalah suatu keadaan di mana seorang karyawan memihak organisasi tertentu serta tujuan-tujuan dan keinginannya untuk mempertahankan keanggotaan dalam organisasi tersebut. Achmad, (2009) dimana penelitian tentang pengaruh komitmen organisasional dan profesional pada kepuasan kerja audit dengan motivasi sebagai variabel intervening. Dimana hasilnya mempunyai pengaruh positif dan signifikan pada kepuasan kerja sebagai variabel intervening.

Rahadyan, Probo dan Andi, (2008) dimana penelitian tentang pengaruh komitmen organisasional dan frofesional pada kepuasan kerja audit dengan motivasi sebagai variabel intervening, yang hasilnya mempunyai pengaruh positif dan signifikan terhadap kepuasan kerja sebagai variabel intervening. Ardiani Ika Sulistyawati (2012), dimana Pengaruh komitmen organisasional dan profesionalpada kepuasan kerja audit motivasi sebagai variabel intervening, dimana hasilnya mempunyai pengaruh positif dan signifikan terhadap kepuasan kerja sebagai variabel interveng.

H6 : Diduga Komitmen Organisasional berpengaruh positif dan signifikan melalui Motivasi sebagai variabel intervening terhadap Kepuasan Kerja. 


\section{Pengaruh Profesional dengan Motivasi sebagai variabel intervening terhadap kepuasan kerja}

Menurut (Oerip dan Uetomo,2000) Profesionalisme adalah prilaku,cara,dan kualitas yang menjadi ciri suatu profesi. Seseorang di katakan profesional apabila pekerjaannya memiliki ciri standar teknik atau etika suatu profesi. Tiffin, (2000) Berpendapat bahwa kepuasan kerja berhubungan erat dengan sikap dari karyawan terhadap pekerjaannya sendiri, kondisi kerja, kerjasama antara pimpinan dengan karyawan. Kegembiraan yang dirasakan seseorang akan memberikan dampak positif baginya.

Dista Amalia, (2015) dimana pengaruh komitmen komitmen organisasi, profesional dan model kepemimpinan pada kepuasan kerja dengan motivasi sebagai variabel intervening, dimana hasilnya mempunyai pengaruh positif dan siknifikan pada motivasi sebagai variabel interveng.

H7 : Diduga Profesional berpengaruh positif dan signifikan melalui Motivasi sebagai variabel intervening terhadap Kepuasan Kerja.

\section{METODE PENELITIAN}

Penelitian ini termasuk pada penelitian kuantitatif yang mana ada angkaangka yang terdapat pada penelitian ini. penelitian kuantitatif menggunakan skala numeric, berbasis pola alur deduktif, dimana untuk menjawab rumusan masalah digunakan teori atau konsep untuk dapat merumuskan hipotesis.Populasi merupakan suatu wilayah generalisasi yang terdiri dari objek yang mempunyai kuantitas dan karakteristik tertentu yang ditetapkan oleh peneliti untuk di pelajari dan kemudian ditarik kesimpulannya.Oleh karena itu dapat disimpulkan bahwa populasi dapat berupa subyek (orang) ataupun objek (tempat) yang karakteristik berbeda dan bisa diteliti. Dalam penelitian ini peneliti mengambil populasi pada 55 pegawai PNS Di Dinas Pendidikan Kepemudaan dan Olahraga Di Solok Selatan, Populasi yang ada akan diambil sejumlah tertentu sebagaisampel. Pengambilan sampel penelitian dilakukan dengan metode purposive sampling. Sedangkan untuk teknik pengumpulan data didapat melalui Survei, Observasi, Interview, dan Dokumentasi yang mana data bisa di dapat langsung pada pegawai Dadan Keuangan Daerah Provinsi Suamatera Barat yang telah memplubikasikan ringkasan berdasarkan objek yang dibutuhkan.

\section{Teknik Analisis Data}

Teknik analisis data yang digunakan dalam penelitian ini adalah metode analisis statistik. Analisis data menggunakan SPSS 16, yang dimana teknik analisis data yang digunakan oleh peneliti adalah:

1. Uji Instrumen Data

a. Uji Validitas yaitu suatu langkah untuk melakukan pengujian terhadap validitas darisuatu contentinstrumen, dengan tujuan untuk mengukur ketepatan yang digunakan oleh penelitian, Uji validitas ini dikatakan valid apabila semua indikator-indikator yang digunakan diatas angka 0,30 .

b. Uji Reliabilitas Uji reliabilitas merupakan suatu ukuran kestabilan ataupun konsistensi dalam menjawab responden hal itu berkaitan dengan konstruk-konstruk pertanyaan yang merupakan kriteria dalam 
variabel maka disusun dalam bentuk kuisioner. Jika $\mathrm{r}$ Alpha, serta $\mathrm{r}>$ 0,60 maka dimensi tersebut reliabel. Jika $r$ Alpha, serta $r<0,60$ maka dimensi tersebut tidak reliabel.

2. Statistik Deskriptif Analisis

Statistik deskriptif adalah penyajian data secara numerik.Statistik deskriptif menyajikan ukuran-ukuran numerik yang sangat penting bagi data sampel.Statistik deskriptif juga digunakan untuk mengetahui nilai rata-rata, minimal, maksimal dan standar deviasi dari variabel-variabel yang diteliti.

3. Uji Asumsi Klasik

Uji asumsi klasik digunakan untuk menguji apakah model regresi benar-benar menunjukkan hubungan yang signifikan dan representatif. Ada tiga pengujian dalam uji asumsi klasik, yaitu:

a. Uji normalitas data Pengujian normalitas dilakukan untuk mengetahui sebuah data berdistribusi normal atau tidak. Jika nilai probabilitas $>0,05$ maka Ho diterima, Jika nilai probabilitas $<0,05$ maka Ho ditolak

b. Uji Heteroskedastisitas untukmenguji apa benar dalam model regresi terjadi ketidak sama anvariance dari residual satu pengamatan kepengamatan yang lain. Jika variance residual hanya satu pengamatan tetap, dapat disimpulkan homo skedastisitas berbeda yaitu heteroskedastisitas Jikapvalue $>0,05$ tidak signifikan berarti tidak terjadi heteroskedastisitas artinya model regresi lolos uji heteroskedastisitas.

4. Analisis Regresi Berganda

a. Regresi Liniar berganda

Model persamaan regresi untuk melihat keputusan pegawai sebagai akibat dari pengaruh komitmen organisasional, profesional dan Kepuasan kerja adalah sebagai berikut :

$$
\begin{aligned}
& \mathrm{Y}=\alpha+\beta_{1} \mathrm{X} 1+\beta_{2} \mathrm{X} 2+\mathrm{Z} \\
& \text { Dimana }: \mathrm{Y}=\text { Kepuasan Kerja } \\
& \mathrm{X} 1=\text { Komitmen Organisasi } \\
& \mathrm{X} 2 \quad=\text { Profesional } \\
& \alpha \quad=\text { Koefisien Konstanta } \\
& \beta 1 \quad=\text { Koefisien regresi untuk komitmen organisasional } \\
& \beta 2 \quad=\text { Koefisien untuk Profesional } \\
& \mathrm{Z} \quad=\text { Motivasi. }
\end{aligned}
$$

b. Regresi liniar sederhana

Regresi linear sederhana adalah salah satu teknik statistik yang digunakan untuk mengetahui pengaruh satu variable bebas terhadap satu variabel terikat. penelitian ini adalah untuk mengetahui pengaruh variabel kepuasan kerja terhadap komitmen organisasi pegawai dengan persamaan sebagai berikut :

$\mathrm{Y}=\mathrm{a}+\mathrm{bI}+\mathrm{Z}$

$\mathrm{Y}$ : Kepuasan Kerja

a : Konstanta

b1 : Koefisien Regresi untuk Komitmen Organisasional

$\mathrm{Z}$ : Motivasi sebagai Variabel Intervening. 


\section{UjiHipotesis}

Uji ini digunakan untuk mengetahui pengaruh bersama-sama variabel bebas terhadap varibel terikat (Pottale, 2016).

a. Uji F Uji simultan dengan F-test menurut Nugroho (2005) bertujuan untuk mengetahui pengaruh bersama-sama variabel independen terhadap variabel dependen. Hasil uji $\mathrm{F}$ ini pada output SPSS dapat dilihat pada tabel Anova. Hasil uji F menunjukkan variabel independen secara bersama-sama berpengaruh terhadap dependen jika p-value (pada kolom Sig). Lebih kecil dari level of significant yang ditentukan atau F hitung (pada kolom F) lebih besar dari $\mathrm{F}$ tabel.

b. Uji Parsial (Uji T) pengujian koefisien regresi masing-masing variabel independen terhadap dependen untuk melihat seberapa besar pengaruh dari variabel independen terhadap variabel dependen.

c. Analisis determinan $\left(\mathrm{R}^{2}\right)$ dimaksudkan untuk mengetahui tingkat ketepatan paling baik dalam analisis regeresi, dimana hal yang ditunjukan oleh besarnya koefisien determinasi $\left(\mathrm{R}^{2}\right)$ antara nol (0) dan (1). Koefisien determinasi nol variable independent sama sekali tidak berpengaruh terhadap variable dependen.

HASIL DAN PEMBAHASAN

Karakteristik Responden Berdasarkan Jenis Kelamin, Usia, dan Pendidikan

Tabel 1

Profil Responden $(\mathbf{n}=55)$

\begin{tabular}{|l|l|c|c|}
\hline \multicolumn{1}{|c|}{ Profil } & \multicolumn{1}{|c|}{ Kategori } & $\begin{array}{c}\text { Jumlah } \\
\text { (orang) }\end{array}$ & $\begin{array}{c}\text { Persentase } \\
(\%)\end{array}$ \\
\hline \multirow{3}{*}{ Jenis Kelamin } & Laki-laki & 23 & 41.8 \\
\cline { 2 - 4 } & Perempuan & 32 & 58.2 \\
\hline \multirow{5}{*}{ Usia } & $18-25$ thn & 5 & 9.1 \\
\cline { 2 - 4 } & $25-35$ thn & 13 & 23.6 \\
\cline { 2 - 4 } & $36-46$ thn & 16 & 29.1 \\
\cline { 2 - 4 } & >46 thn & 21 & 38.2 \\
\hline \multirow{5}{*}{ Pendidikan } & SMA/sederajat & 7 & 12.7 \\
\cline { 2 - 4 } & Diploma & 8 & 14.5 \\
\cline { 2 - 4 } & S1 & 22 & 40.0 \\
\cline { 2 - 4 } & S2 & 0 & 32.7 \\
\hline & S3 & & 0 \\
\hline
\end{tabular}

\section{Sumber: Lampiran 1.}

Berdasarkan tabel 1 dapat dilihat bahwa profil responden pertama dibedakan atas jenis kelamin. Berdasarkan kategori ini responden yang paling banyak adalah perempuan yaitu sebanyak 32 orang $(41.8 \%)$ dan sisanya adalah laki-laki yaitu sebanyak 23 orang (58.2\%). Hal ini sesuai dengan tugas yang diberikan oleh pegawai pada Dinas Pendidikan Kepemudaan, dan Olahraga Di Kabupaten Solok Selatan karena lebih banyak membutuhkan pegawai perempuanyang biasanya 
perempuan lebih sigap dan cepatan dalam menyelesaikan pekerjaan dan dapat mengerjakan tugas-tugas tanpa mengalami hambatan berarti jika dibandingkan dengan laki-laki.

Profil responden kedua dibedakan atasusia. Berdasarkan kategori ini responden yang paling banyak adalah usia antara 18-25 tahun yaitu sebanyak 5 orang (9.1\%), kemudian usia antara 25-35 tahun yaitu sebanyak 13 orang (23.6\%), usia antara 36-46 tahun sebanyak 16 orang (29.1\%), Selanjutnya diikuti usia >46 tahun yaitu sebanyak 21 orang (38.2\%). Hal ini menjelaskan bahwa pegawai Di Dinas Pendidikan Kepemudaan, dan Olahraga di Kabupaten Solok Selatan lebih banyak pada usia antara $>46$ tahun.

Profil responden ketiga dibedakan atas pendidikan. Berdasarkan kategori ini responden yang paling banyak adalah berpendidikan SMA yaitu sebanyak 7 orang $(12.7 \%)$, kemudian diikuti dengan pendidikan Diploma yaitu sebanyak 8 orang $(14.5 \%)$, selanjutnya pendidikan (S1) sebanyak 22 orang (40.0\%), dan pendidikan (S2) sebanyak 18 orang (32.7\%). Hal ini disebabkan pada awal perekrutan pegawai diterimanya pegawai dengan ijazah S2 bertujuan untuk membantu tugastugas yang dibebankan kepada pegawai yang berijazah sarjana yang sesuai dengan tingkat pendidikan yang dimiliki pegawai di Dinas Pendidikan Kepemudaan, dan Olahraga Di Kabupaten Solok Selatan .Jadi dapat disimpulkan bahwa responden pada penelitian ini pada umumnya berjenis kelamin Perempuan, berusia antara $>46$ tahun, dengan tingkat pendidikan S2.

\section{Analisis Regresi Berganda}

\section{Regresi liniar berganda}

Model persamaan regresi untuk melihat keputusan pembelian konsumen sebagai akibat dari pengaruh persepsi kualitas, persepsi kesesuaian dan Kepuasan kerja adalah sebagai berikut :

Tabel 2

Uji Regresi linear berganda variabel Komitmen dan Profesional terhadap Kepuasan Kerja

Coefficients $^{\text {a }}$

\begin{tabular}{|c|c|c|c|c|c|c|}
\hline & & \multicolumn{2}{|c|}{$\begin{array}{l}\text { Unstandardized } \\
\text { Coefficients }\end{array}$} & \multirow{2}{*}{\begin{tabular}{c|}
$\begin{array}{c}\text { Standardized } \\
\text { Coefficients }\end{array}$ \\
Beta
\end{tabular}} & \multirow[b]{2}{*}{$\mathrm{T}$} & \multirow[b]{2}{*}{ Sig. } \\
\hline \multicolumn{2}{|c|}{ Model } & B & Std. Error & & & \\
\hline 1 & (Constant) & 24.337 & 8.202 & & 2.967 & .005 \\
\hline & $\begin{array}{l}\text { Komitmen } \\
\quad \text { Organisasional }\end{array}$ & .385 & .084 & .533 & 4.566 & .000 \\
\hline & Profesional & .278 & .177 & .184 & 1.572 & .122 \\
\hline
\end{tabular}

a. Dependent Variable: Kepuasan Kerja

$\mathrm{Y}=\alpha+\beta_{1} \mathrm{X} 1+\beta_{2} \mathrm{X} 2$

$\mathrm{Y}=24.337+0,385 \mathrm{X} 1+0,278 \mathrm{X} 2$

Berdasarkan tabel diatas diketahui hasil uji regresi linear berganda. Nilai konstan dalam kasus ini sebesar 24.337. Angka ini mempunyai arti bahwa jika tidak ada komitmen organisasional maka konsisten kepuasan kerja sebesar 24.337.Nilai koefisien regresi komitmen organisasional sebesar 0,385, 
professional sebesar 0,278. Angka tersebut menggandung arti bahwa setiap penambahan $1 \%$ tingkat komitmen organisasional sebesr 0,385, professional sebasar 0,278 maka masing-masing variabel meningkat. Maka dapat dikatakan bahwa komitmen organisasional berpengaruh signifikan terhadap kepuasan kerja, (profesional) tidak berpengaruh positif dan signifikan terhadap kepuasan kerja.

Tabel 3

Uji Regresi Liniar berganda variabel Komitmen Organisasi, Profesional dan Motivasi sebagai intervening terhadap Kepuasan Kerja

Coefficients $^{\mathbf{a}}$

\begin{tabular}{|c|c|c|c|c|c|c|}
\hline & & \multicolumn{2}{|c|}{$\begin{array}{r}\text { Unstandardized } \\
\text { Coefficients }\end{array}$} & \multirow{2}{*}{\begin{tabular}{|c}
$\begin{array}{c}\text { Standardized } \\
\text { Coefficie } \\
\text { nts }\end{array}$ \\
Beta
\end{tabular}} & \multirow[b]{2}{*}{$\mathrm{T}$} & \multirow[b]{2}{*}{ Sig. } \\
\hline \multicolumn{2}{|c|}{ Model } & $\mathrm{B}$ & Std. Error & & & \\
\hline 1 & (Constant) & 25.557 & 8.166 & & 3.130 & .003 \\
\hline & Komitmen Organisasi & .296 & .104 & .411 & 2.848 & .006 \\
\hline & Profesional & .087 & .220 & .058 & .397 & .693 \\
\hline & Motivasi & .694 & .487 & .257 & 1.426 & .160 \\
\hline
\end{tabular}

a. Dependent Variable: Kepuasan Kerja

$\mathrm{Y}=\alpha+\beta_{1} \mathrm{X} 1+\beta_{2} \mathrm{X} 2+\mathrm{Z}$

$\mathrm{Y}=25.557+0,296 \mathrm{X} 1+0,087 \mathrm{X} 2+0,694 \mathrm{Z}$

Berdasarkan tabel diatas diketahui hasil uji regresi linear berganda. Nilai konstan dalam kasus ini sebesar 25.557. Angka ini mempunyai arti bahwa jika tidak ada komitmen organisasional maka konsisten kepuasan kerja sebesar 25.557.Nilai koefisien regresi sebesar komitmen organisasional sebesar 0,296, professional sebesar 0,087 dan motivasi sebesar 0,694. Angka tersebut menggandung arti bahwa setiap penambahan $1 \%$ tingkat komitmen organisasional sebesr 0,296, professional sebasar 0,087 dan motivasi sebesar 0,694 maka masing-masing variabel meningkat. Maka dapat dikatakan bahwa komitmen organisasional berpengaruh signifikan terhadap kepuasan kerja, (profesional dan motivasi) tidak berpengaruh positif dan signifikan terhadap kepuasan kerja.

\section{Regresi liniar sederhana}

Regresi linear sederhana adalah salah satu teknik statistik yang digunakan untuk mengetahui pengaruh satu variable bebas terhadap satu variabel terikat. 
Tabel 4

Hasil Uji Regresi liniar sedehana

Coefficients $^{\text {a }}$

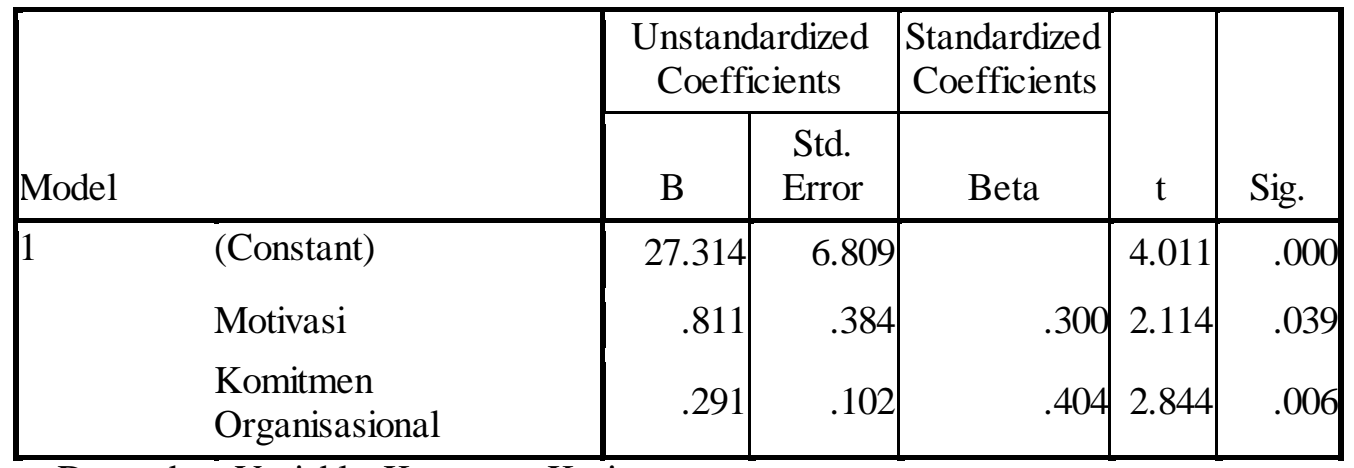

a. Dependent Variable: Kepuasan Kerja

$\mathrm{Y}=\mathrm{a}+\mathrm{bI}+\mathrm{Z}$

$\mathrm{Y}=27.314+0,291 \mathrm{~b} 1+0,811 \mathrm{Z}$

Berdasarkan tabel diatas diketahui hasil uji regresi linear sederhana.

Nilai konstan dalam kasus ini sebesar 27,314. Angka ini mempunyai arti bahwa jika tidak ada komitmen organisasional maka konsisten kepuasan kerja sebesar 27,314.Nilai koefisien regresi sebesar komitmen organisasional sebesar 0,291 dan motivasi sebesar 0,811. Angka tersebut menggandung arti bahwa setiap penambahan $1 \%$ tingkat komitmen organisasional sebesr 0,291 dan motivasi sebesar 0,811 maka masing-masing variabel meningkat. Maka dapat dikatakan bahwa komitmen organisasional dan motivasi berpengaruh positif terhadap kepuasan kerja.

\section{Pembahasan}

\section{Pengaruh Komitmen Organisasional Terhadap Kepuasan Kerja}

Berdasarkan hasil dari uji $\mathrm{T}$ pada tabel 19 dapat dilihat bahwa variabel komitmen organisasional mempunyai pengaruh yang signifikan terhadap kepusan kerja karena tingkat signifikannya lebih kecil dari 0,05 yaitu 0,006. Untuk itu, penulis menarik kesimpulan bahwa komitmen organisasional dengan indikator Komitmen efektif (Affective commitment), Komitmen berkelanjutan (Continuance commitment), Komitmen normatif (Normative commitment) merupakan salah satu faktor yang mempunyai pengaruh yang positif dan signifikan terhadap kepuasan kerja di Dinas Pendidikan Kepemudaan dan Olahraga Kabupaten Solok Selatan.

Hal itini berarti bahwa H1 diterima yaitu diduga bahwa komitmen organisasional mempunyai pengaruh positif dan signifikan terhadap kepuasan kerja pegawai di Dinas Pendidikan Kepemudaan dan Olahraga di Solok Selatan. Menurut Yudi Syarif (2006) Komitmen organisasional merupakan dorongan dalam diri individu berbuat sesuatu agar dapat menunjang keberhasilan organisasi dengan tujuan lebih mengutamakan kepentingan organisasi.

Hasil Penelitian ini didukung oleh penelitian yang telah dilakukan oleh Rahadyan, Probo dan Andi, (2008) dengan penelitian pengaruh komitmen organisasional dan professional terhadap kepuasan kerja auditor dengan motivasisebagai variabel intervening. Hal ini menunjukan bahwa komitmen organisasional berpengaruh positif terhadap kepuasan kerja. 


\section{Pengaruh Profesional terhadap Kepuasan Kerja}

Berdasarkan hasil dari uji $\mathrm{T}$ pada tabel 19 dapat dilihat bahwa variabel profesional mempunyai pengaruh yang tidak signifikanterhadap kepusan kerja karena tingkat signifikannya lebih besar dari 0,05 yaitu 0,693. Untuk itu, penulis menarik kesimpulan bahwa professional dengan indikatorTingkat pendidikan, Pelatihan yang telah dilakukan pegawai, Tingkat disiplin dan Semangat kerja serta kreativitas pegawai merupakan salah satu faktor yang mempunyai pengaruh yang positif tetapi tidak signifikan terhadap kepuasan kerja di Dinas Pendidikan Kepemudaan dan Olahraga di Solok Selatan.

Hal ini berarti bahwa $\mathrm{H} 2$ ditolak yaitu diduga bahwa profesional mempunyai pengaruh positif dan signifikan terhadap kepuasan kerja pegawai di Dinas Pendidikan Kepemudaan dan Olahraga di Solok Selatan.Penelitian ini didukung oleh hasil penelitian yang dilakukan oleh Menurut Sigian (2000) Propesionalisme adalah keadaan dalam pelaksanaan tugas sehingga terlaksana dengan mutu tinggi, waktu yang tepat, cermat dan dengan prosedur yang mudah di pahami dan diikuti oleh pelanggan.

Hasil penelitian ini tidak mendukung karna berlawanan dengan penelitian sebelumnya yang di lakukan oleh Gunawan, (2006) Pengaruh Profesionalisme Dan Komitmen Organisasi Terhadap Kinerja Internal Auditor Dengan Kepuasan Kerja Sebagai Variabel Intervening (Studi Empiris Pada Internal Auditor Pt. Bank Abc), di mana hasil penelitian tersebut adalah profesional mempunyai pengaruh yang signifikan terhadap kepuasan kerja.

\section{Pengaruh Komitmen Organisasional terhadap Motivasi sabagai Variabel Intervening}

Berdasarkan hasil dari uji $\mathrm{T}$ pada tabel 18 dapat dilihat bahwa variabel profesional mempunyai pengaruh yang tidak signifikan terhadap kepusan kerja karena tingkat signifikannya lebih kecil dari 0,05 yaitu 0,000. Untuk itu, penulis menarik kesimpulan bahwa komitmen organisasional dengan indikator Komitmen efektif (Affective commitment), Komitmen berkelanjutan (Continuance commitment), Komitmen normatif (Normative commitment) merupakan salah satu faktor yang mempunyai pengaruh yang positif dan signifikan terhadap motivasi sebagai variabel intervening di Dinas Pendidikan Kepemudaan dan Olahraga di Solok Selatan.

Hal itu berarti bahwa H3 diterima yaitu diduga bahwa komitnen organisasional berpengaruh positif dan signifikan terhadap motivasi sebagai variabel intervening di Dinas Pendidikan Kepemudaan dan Olahraga di Solok Selatan.

Hasil penelitian ini didukung oleh penelitian sebelumnya yang dilakukan oleh Rahadyan, Probo dan Andi, (2008) dengan judul penelitian Pengaruh Komitmen Organisasional Dan Profesional Terhadap Kepuasan Kerja Auditor Dengan Motivasi Sebagai Variabel Intervening (Studi Empiris Pada Kantor Akuntan Publik Di Semarang), di mana hasil penelitian tersebut menyatakan bahwa komitmen organisasi mempunyai pengaruh yang positif dan signifikan terhadap kepuasan kerja. 


\section{Pengaruh Profesional terhadap Motivasi sebagai Variabel Intervening}

Berdasarkan hasil dari uji $\mathrm{T}$ pada tabel sebelumnya dapat dilihat bahwa variabel profesional mempunyai pengaruh yang tidak signifikan terhadap motivasi karena tingkat signifikannya lebih besar dari 0,05 yaitu 0,122. Untuk itu, penulis menarik kesimpulan bahwa professional denganindikator Tingkat pendidikan, Pelatihan yang telah dilakukan pegawai, Tingkat disiplin dan Semangat kerja serta kreativitas pegawai merupakan salah satu faktor yang mempunyai pengaruh yang positif tetapi tidak signifikan terhadap kepuasan kerja di Dinas Pendidikan Kepemudaan dan Olahraga di Solok Selatan.

Hal ini berarti bahwa $\mathrm{H} 4$ ditolak yaitu diduga bahwa profesional mempunyai pengaruh positif dan signifikan terhadap motivasi sebagai variabel intervening di Dinas Pendidikan Kepemudaan dan Olahraga di Solok Selatan.

Hasil penelitian ini tidak mendukung karna berlawanan dengan penelitian sebelumnya yang di lakukan oleh Dista Amalia, (2015) Pengaruh Komitmen Organisasi, Komitmen Profesional Dan Gaya Kepemimpinan Terhadap Kepuasan Kerja Dengan Motivasi Sebagai Variabel Intervening(Studi Empiris pada Kantor Akuntan Publik di Semarang), di mana hasil penelitian tersebut adalah profesional mempunyai pengaruh yang signifikan terhadap mitivasi sebagai variabel intervening.

Pengaruh Motivasi sebagai Variabel Intervening terhadap Kepuasan Kerja

Berdasarkan hasil dari uji T 19 dapat dilihat bahwa variabel motivasi sebagai variabel intervening mempunyai pengaruh pengaruh yang positif tetapi tidak signifikan terhadap kepuasan kerja karena tingkat signifikannya lebih besar dari 0,05 yaitu 0,160. Untuk itu, penulis menarik kesimpulan bahwa motivasi sebagai variabel intervening dengan dimensi motivasi internal dan motivasi eksternalmerupakan salah satu faktor yang mempunyai pengaruh yang positif tetapi tidak signifikan terhadap kepuasan kerja di Dinas Pendidikan Kepemudaan dan Olahraga di Solok Selatan.

Hal ini berarti bahwa H5ditolak yaitu diduga bahwa motivasi sebagai variabel intervening mempunyai pengaruh positif dan signifikan terhadap motivasi sebagai variabel intervening di Dinas Pendidikan Kepemudaan dan Olahraga di Solok Selatan.

Hasil penelitian ini didukung oleh penelitian sebelumnya yang dilakukan oleh Rahadyan, Probo dan Andi, (2008) dengan judul penelitian Pengaruh Komitmen Organisasional Dan Profesional TerhadapKepuasan Kerja Auditor Dengan MotivasiSebagai Variabel Intervening(Studi Empiris Pada Kantor Akuntan Publik Di Semarang), di mana hasil penelitian tersebut adalah motivasi mempunyai pengaruh yang kecil dan tidak signifikan terhadap kepuasan kerja auditor.

\section{Pengaruh Komitmen Organisasional dengan Motivasi sebagai Variabel Intervening terhadap Kepuasan Kerja}

Berdasarkan hasil uji $\mathrm{T}$ pada tabel 19 nilai dari standardized beta komitmen organisasional sebesar 0,411 dan signifikan pada 0,006 maka dapat disimpulkan bahwa pengaruh langsung variabel Komitmen Organisasional terhadap kepuasan kerja sebesar 0,411. Berdasarkan hasil dari uji T 4.18 nilai standardized beta komitmen organisasional melalui variabel motivasi sebesar 0,533 dan signifikan pada 0,000 sedangkan berdasarkan tabel 4.19 nilai 
standardized beta motivasi sebesar 0,257 dan signifikan pada 0,160 sehingga pengaruh tidak langsung variabel komitmen Organisasional terhadap kepuasan kerja melalui variabel intervening motivasi sebesar $0,533 * 0,257=0,136$. Berdasarkan perhitungan tersebut penulis menyimpulkan bahwa pengaruh langsung Komitmen Organisasional terhadap Kepuasan kerja ternyata lebih besar dibandingkan pengaruh tidak langsung variabel Komitmen Organisasional terhadap Kepuasan Kerja melalui variabel intervening Motivasi $(0,411>0,136)$.

Hal ini berarti bahwa H6 ditolakyaitu diduga komitmen organisasional berpengaruh positif dan signifikan melalui motivasi sebagai variabel intervening terhadap kepuasan kerja pegawai di Dinas Pendidikan Kepemudaan dan Olahraga di Solok Selatan.

Hasil penelitian ini didukung oleh penelitian sebelumnya yang dilakukan olehRahadyan, Probo dan Andi, (2008) dengan judul penelitian Pengaruh Komitmen Organisasional Dan Profesional Terhadap Kepuasan Kerja Auditor Dengan Motivasi Sebagai Variabel Intervening (Studi Empiris Pada Kantor Akuntan Publik Di Semarang), di mana hasil penelitian tersebut adalah komitmen organisasional berpengaruh secara langsung terhadap kepuasan kerja auditor tanpa adanya motivasi sebagai variabel intervening. Rendahnya pengaruh motivasi auditor terhadap kepuasan kerja tersebut kurang dapat menjadi perantara antara komitmen organisasional dengan kepuasan kerja.Hal tersebut mengindikasikan bahwa hubungan yangterjadi sebenarnya adalah hubungan langsung, maka pengaruh variabel intervening dalam hubungan antara komitmen organisasional dan kepuasan kerja.

\section{Pengaruh Profesional dengan Motivasi sebagai Variabel Intervening terhadap Kepuasan Kerja}

Berdasarkan hasil uji $\mathrm{T}$ pada tabel 19 nilai dari standardized beta profesional sebesar 0,058 dan signifikan pada 0,693 maka dapat disimpulkan bahwa pengaruh langsung variabel Komitmen Organisasional terhadap kepuasan kerja sebesar 0,058. Berdasarkan hasil dari uji $\mathrm{T} 4.18$ nilai standardized beta profesional melalui variabel motivasi sebesar 0,184 dan signifikan pada 0,122 sedangkan berdasarkan tabel 4.19 nilai standardized beta motivasi sebesar 0,257 dan signifikan pada 0,160 sehingga pengaruh tidak langsung variabel profesional terhadap kepuasan kerja melalui variabel intervening motivasi sebesar $0,184 * 0,257=0,047$. Berdasarkan perhitungan tersebut penulis menyimpulkan bahwa pengaruh langsung profesional terhadap Kepuasan kerja ternyata lebih besar dibandingkan pengaruh tidak langsung variabel Komitmen Organisasional terhadap Kepuasan Kerja melalui variabel intervening Motivasi $(0,058>0,047)$.

Hal ini berarti bahwa $\mathrm{H} 7$ ditolak yaitu diduga profesional berpengaruh positif dan signifikan melalui motivasi sebagai variabel intervening terhadap kepuasan kerja pegawai di Dinas Pendidikan Kepemudaan dan Olahraga di Solok Selatan.

Hasil penelitian ini didukung oleh penelitian sebelumnya yang dilakukan oleh Rahadyan, Probo dan Andi, (2008) dengan judul penelitian Pengaruh Komitmen Organisasional Dan Profesional Terhadap Kepuasan Kerja Auditor Dengan Motivasi Sebagai Variabel Intervening (Studi Empiris Pada Kantor Akuntan Publik Di Semarang), di mana hasil penelitian tersebut adalah komitmen organisasional berpengaruh secara langsung terhadap kepuasan kerja auditor tanpa adanya motivasi sebagai variabel intervening. Rendahnya pengaruh motivasi auditor terhadap kepuasan kerja tersebut kurang dapat menjadi perantara antara komitmen organisasional dengan kepuasan kerja.Hal tersebut mengindikasikan bahwa hubungan yangterjadi sebenarnya adalah 
hubungan langsung, maka pengaruh variabel intervening dalam hubungan antara komitmen organisasional dan kepuasan kerja.

\section{KESIMPULAN}

Dari hasil pengujian hipotesis yang telah dilakukan mengenai analisis Pengaruh Komitmen Organisasional dan Profesional terhadap Kepuasan Kerja Pegawai dengan Motivasi sebagai Variabel Intervening maka dapat ditarik kesimpulan sebagai berikut:

1.Variabel Komitmen Organisasional terhadap Kepuasan Kerja Pegawai dengan nilai sig $0,000<0,05$, maka hipotesis diterima karna mendukung hipotesis $1\left(\mathrm{H}_{1}\right)$ bahwa Komitmen Organisasinal berpengaruh positif dan signifikan terhadap Kepuasan Kerja pegawai.

2)Variabel Profesional terhadap Kepuasan Kerja Pegawai dengan nilai sig 0,693 > 0,05, maka hipotesis di tolak karna mendukung hipotesis $2\left(\mathrm{H}_{2}\right)$ bahwa Profesional tidak berpengaruh signifikan terhadap Kepuasan Kerja pegawai.

3) Variabel Komitmen Organisasional terhadap Motivasi sebagai Variabel Intervening dengan nilai sig $0,000<0,05$, maka hipotesis di terima karna mendukung hipotesis 3 $\left(\mathrm{H}_{3}\right)$ bahwa Komitmen Organisasional berpengah positif dan signifikan terhadap Motivasi sebagai Variabel Intervening.

4) Variabel Profesional terhadap Motivasi sebagai Varariabel Intervening dengan nilai sig 0,122>0,05, maka hipotesis di tolak karena mendukung hipotesis $4\left(\mathrm{H}_{4}\right)$ bahwa Profesional tidak berpengah signifikan terhadap Motivasi sebagai Variabel Intervening.

5) Variabel Motivasi sebagai Variabel Intervening terhadap Kepuasan Kerja dengan nilai sig 0,160>0,05, maka hipotesis di tolak karena mendukung hipotesis $5\left(\mathrm{H}_{5}\right)$ bahwa Motivasi sebagai Variabel Intervening tidak berpengaruh signifikan terhadap Kepuasan Kerja Pegawai.

6) Variabel Komitmen Organisasional dengan Motivasi sebagai Variabel Intervening terhadap Kepuasan Kerja dengan nilai sig 0,136>0,05, maka hipotesis di tolak karena mendukung hipotesis $6\left(\mathrm{H}_{6}\right)$ bahwa Komitmen Organisasional dengan Motivasi sebagai Variabel Intervening tidak berpengaruh signifikan terhadap Kepuasan Kerja Pegawai.

7) Variabel Profesional dengan Motivasi sebagai Variabel Intervening terhadap Kepuasan Kerja dengan nilai sig 0,047 >0,05, maka hipotesis di tolak karena mendukung hipotesis $7\left(\mathrm{H}_{7}\right)$ bahwa Profesional dengan Motivasi sebagai Variabel Intervening tidak berpengaruh signifikan terhadap Kepuasan Kerja Pegawai.

\section{UCAPAN TERIMAKASIH}

Dengan selesainya dalam artikel penelitian Bapak Febryandhie Ananda, SE, M.Si selaku ketua STIE "KBP” Padang yang telah memberikan bimbingan dan fasilitas selama penulis menjadi mahasiswi.Ibu Lidya Martha, SE, MM selaku wakil ketua Sekolah Tinggi Ilmu Ekonomi "Keuangan, Perbankan dan Pembangunan" Padang.Ibu Maria Magdalena S.Pd,MM selaku pembimbing Akademik Manajemen tahun 2014.Ibu Febsri Susanti, SEI, MM selaku ketua program studi manajemen Sekolah Tinggi Ilmu Ekonomi "Keuangan, Perbankan dan Pembangunan" Padang.Ibu Aminar Sutra Dewi, SE, M. Si selaku Pembimbing skripsi dan artikel yang memberikan izin kepada peneliti untuk pengambilan dan pengumpulan data dalam penelitian ini.

\section{DAFTAR PUSTAKA}

Achmad, B. (2009). Pengaruh Komitmen Organisasional dan Profesional Terhadap Kepuasan Kerja Auditor Dengan Motivasi Sebagai Variabel 
Intervening (Studi Pada KAP di Jawa Tengah dan DIY). Stikubank, Semarang.

Achmad, B. (2013). Pengaruh Komitmen Terhadap Kepuasan Kerja Auditor Dengan Motivasi Sebagai Variabel Intervening (Studi Empirik Pada Kantor Akuntan Publik di Jawa tengah, 20(2), 150-170.

Aldi, Y., \& Susanti, F. (2019). Pengaruh Stress Kerja Dan Motivasi Kerja Terhadap Prestasi Kerja Karyawan Pada PT. Frisian Flag Indonesia Wilayah Padang. https:/doi.org/10.31227/osf.io/et4rn

Dista Amalia, A. C. R. (2015). Pengaruh Komitmen Organisasi, Komitmen Profesional Dan Gaya Kepemimpinan Terhadap Kepuasan Kerja Dengan Motivasi Sebagai Variabel Intervening (Studi Empiris pada Kantor Akuntan Publik di Semarang), 2 No.1.

Fendi, Z., \& Susanti, F. (2018). Pengaruh Kepuasan Keria Terhadap Turnover Intention Dengan Komitmen Organisasi Sebagai Variabel Intervening Pada CV. Belibis Pariaman. https://doi.org/10.31227/osf.io/wumgx

Gunawan, C. (2006). Pengaruh ProfesionalismeDan Komitmen Organisasional Terhadap Kinerja Internal Auditor, Dengan Kepuasan Kerja Sebagai Variabel Intervening(Studi Empiris Pada Internal Auditor PT. BANK $A B C)$.

Mayliza, R. (2019). Pengaruh Kompensasi Finansial, Lingkungan Kerja Dan Motivasi Kerja Terhadap Kinerja Pegawai Pada Kantor PDAM Kota Payakumbuh. https://doi.org/10.17605/OSF.IO/DZXAF

Mayliza, R. (2019). Pengaruh Kepuasan Kerja Dan Loyalitas Kerja Terhadap Organizational Citizenship Behavior (OCB) Pada Pegawai BPKPAD Di Madina. https://doi.org/10.17605/OSF.IO/5PVWB

Mayliza, R. (2019). Pengaruh Gaya Kepemimpinan Dan Disiplin Kerja Terhadap Kinerja Karyawan Dengan Motivasi Kerja Sebagai Variabel Intervening Pada PT. Semen Padang. https//doi.org/10.17605/OSF.IO/FYPQ9

Rahadyan, Probo dan Andi, K. (2008). Pengaruh Komitmen Organisasional dan Profesional Kepuasan Kerja Auditor dengan Motivasi sebagai Variabel Intervening (Studi Empiris pada Kantor Akuntan Publik di Semarang). Bisnis Dan Ekonomi (JBE), 15(1), 80-90.

Robbins, S. dan, \& Judge. (2008). Perilaku Organisasi.

Sari, P. P., \& Dewi, A. S. (2018). Pengaruh Komitmen Organisasional Dan Profesional Terhadap Kepuasan Kerja Dengan Motivasi Sebagai Variabel 
Intervening Pada Pegawai UPT Dinas Kesehatan Puskesmas Air Bangis Pasaman Barat. https //doi.org/10.31219/osf.io/58pw7

Tiffin, A. (2000). Hubungan Motivasi Kerja, Lingkungan Kerja dan Manajerial Atasan dengan Kepuasan Kerja Guru. Jakarta : UNJ.

Trisnaningsih, S. (2001). "Pengaruh Komitmen Terhadap Kepuasan Kerja Auditor: Motivasi Sebagai Variabel Intervening (Studi Empiris Pada KAP di Jawa Timur)." 